\title{
Identification and analysis of non-financial measures that affect investment decisions using the Delphi method
}

\author{
Dr. Mohammad Reza Abbaszadeh \\ Faculty of Economics and Business Administration \\ Ferdowsi University of Mashhad (FUM), Iran \\ S. Tahereh Mehrabankhou (Corresponding Author) \\ Faculty of Economics and Business Administration \\ Ferdowsi University of Mashhad (FUM), Iran \\ Email: tmehrabankhou@yahoo.com
}

Received: November 12, 2012 Accepted: December 15, 2012 DOI: 10.5296/ijafr.v2i2.2858

\begin{abstract}
Though advocates argue that nonfinancial information forms or should form an increasingly important part of investor decision-making, relatively little research has been done to analyze the nonfinancial information currently available or to determine how investors value specific types of nonfinancial information. This study has examined both the availability of specific types of nonfinancial data, as well as the extent to which retail and professional investor value nonfinancial information.

We focused on nine types of information, each of which has received considerable attention from academics and advocates in recent years. We reviewed corporate disclosure practices of several companies across different industry sectors; we conducted surveys with academics that had fields of accounting and economics and investment managers from public of Iran as professional investors.

The goal of our research was to better assess both the supply and demand of nonfinancial reporting in the current investment climate. We believe that the results of this study offer academics, investors, corporations and regulators a clearer picture both of investor desires for nonfinancial information and the ways in which various forms of reporting are used. The results can inform choices about which regulatory approach might be best applied to nonfinancial reporting. They can also support corporate and investor efforts to supplement that regime with voluntary corporate reporting on specific nonfinancial information types.
\end{abstract}

Keywords: Decision making, Decisions of investors, Delphi method, investors, nonfinancial measures 


\section{Mll Macrothink}

International Journal of Accounting and Financial Reporting

ISSN 2162-3082

2012, Vol. 2, No. 2

\section{Introduction}

The primary objective of financial reporting is to provide high-quality financial reporting information concerning economic entities, primarily financial in nature, useful for economic decision making (FASB, 1999; IASB, 2008). Providing high quality financial reporting information is important because it will positively influence capital providers and other stakeholders in making investment, credit, and similar resource allocation decisions enhancing overall market efficiency (IASB, 2008).

Non-financial performance measures are becoming an important type of disclosure in the corporate environment as evidenced by calls for more of this type of disclosure by organizations such as the Enhanced Business Reporting Consortium (EBRC, 2005) and the Institute of Chartered Accountants in England and Wales (ICAEW, 2003). Non-financial performance measures are based on measures that complement financial statements such as "operational measures on customer satisfaction, internal business processes, and the organization's innovation and improvement activities" (Kaplan and Norton, 1992,p. 71).

The importance of this issue is documented within the American Accounting Association's Financial Accounting Standards Committee (AAA FASC, 2002) review of the research literature relating to the disclosure of non-financial performance measures. While this review demonstrated that there was value in non-financial disclosures, it also found that such disclosures were relatively uncommon and that, when they occurred, they were varied and unstructured. The AAA FASC acknowledged that archival studies have found associations between certain types of non-financial disclosures and share prices but cautioned that these results show association and not necessarily evidence of usage.

Over the past two decades, business reporting practices have been heavily criticized by academics and practitioners alike. A stream of empirical accounting research has tested the value relevance of accounting information during different periods. Early studies found a decline in the association between returns, on the one hand, and both earnings and book values, on the other (Francis and Schipper, 1999; Lev an d Zarowin, 1999). However, other studies have found that results are largely dependent on the methods employed (Chang, 1998). Additionally, Brown et al (1998) found no significant change in the relevance of earnings over time.

Theoretically, accounting information is becoming less relevant if it fails to include some intangible values in the balance sheet. Because firms are increasingly relying on intangibles for the future success, this accounting treatment has meant a gradually decreasing relevance of accounting information (Wallman, 1995; Lev and Zarowi, 1999).

In this study, we observed a set of 60non-financial information items by studying the contents of non-financial reports and past researches. The term non-financial information in this study refers to qualitative information outside of the four financial statements.

The aim of this study is to assess the usefulness of non-financial information by using Delphi method. Furthermore, we examined how this information has effect on Decisions of investors. 


\section{Ml Macrothink}

International Journal of Accounting and Financial Reporting

ISSN 2162-3082

2012, Vol. 2, No. 2

This project is meant to better identify those types of information most desired by investors currently, and to identify whether and where there are areas where improvements in data comparability, clarity and reliability would facilitate investors' use of information they find material to their decision-making.

\section{2 .Literature review}

\subsection{Non-financial information}

Over recent years, the level of interest from stakeholders in corporate environmental, social and ethical performance has risen significantly. Non-financial information often referred to as sustainability reporting, enables businesses to be transparent in communicating these non-financial aspects of their management and performance. While non-financial reporting is currently voluntary, it offers significant benefits to organizations in terms of stakeholder engagement and reputation. Proposals to supplement conventional accounting with the use of nonfinancial information (NFI) have exerted a powerful appeal in recent years. Balanced scorecards and similar performance measurement systems have been advocated intensively and are widely used by organizations (e.g., Eccles et al. 2001; Kaplan and Norton 2001a, 2001b, 2001c, 2008). Business risk or strategic-systems audits, which rely on NFI to understand the client's business, have been put forward as a way to conduct efficient high-quality audits in a challenging economic and regulatory environment (Bell et al . 2002; Peecher et al. 2007). Financial analysts use NFI to forecast earnings and stock prices (Dempsey et al. 1997; Chandra et al. 1999; Rajgopal, Venkatachalam, and Kotha 2002; Peecher et al. 2007), and the Financial Accounting Standards Board (FASB) has considered mandating the reporting of nonfinancial measures along with traditional financial statements (FASB 2001).

\subsection{Principles of non-financial reporting}

A sustainability report should address all material (i.e. relevant and significant) issues affecting stakeholders. Both GRI-G3 and AA1000APS provide a selection of principles to be considered when reporting on sustainability. These include:

Inclusivity: AA1000APS states that "inclusivity is much more than a stakeholder engagement process". It outlines it as the commitment to be accountable to those stakeholders that the organization impacts and those stakeholders who have an impact on it. It also enables their participation in identifying issues and finding solutions. In the words of Account Ability: "It is about collaborating at all levels, including governance, to achieve better outcomes."(AA1000APS2008).

Materiality: An issue is considered "material" if it will influence the decisions, actions and performance of an organization or its stakeholders. GRI-G3 defines materiality as "the topics or indicators reflecting an organization's economic, environmental and social impacts that would influence the assessments and decisions of stakeholders."(Global Reporting Initiative Sustainability Reporting Guidelines, 2007).AA1000APS defines materiality as "the analysis of information which takes into consideration sustainability drivers, and accounts for the needs, concerns and expectations of the organization and its stakeholders." 
Responsiveness: Defined in AA1000APS as "how an organization demonstrates its response and accountability to its stakeholders." A responsive organization addresses its material issues and responds to its stakeholders in a comprehensive and balanced manner.

Stakeholder inclusiveness: Similar to responsiveness, the GRI-G3 states that "the reporting organization should identify its stakeholders and explain in its report how it has responded to their reasonable expectations and interests."

Completeness: According to GRI-G3, "completeness is the coverage of the material topics, the GRI-G3 indicators and the definition of the report boundary which sufficiently reflects economic, environmental and social impacts, enabling stakeholder assessment." While completeness is no longer an explicit AA1000 principle in the revised 2008 edition, it remains a key concept to the extent to which materiality inclusivity and responsiveness have been achieved.

\subsection{Delphi studies}

The Delphi study was chosen for comparability but another aim was to seek consensus or judgment on the issues (Beretta, 1996; Green et al., 1999). It was developed by the Rand Corporation in the 1950s and 1960s to elicit expert opinions on future trends or directions in specific areas of study (Dawson and Brucker, 2001).

It allows the grouping and subsequent analysis of the ideas of experts in order to gain a closer understanding of issues that would not be offered by other qualitative or quantitative studies. The reasons for conducting a study using the Delphi method have been summarized by Dawson and Brucker (2001) as firstly, there is no other group communication process than can elicit the same data; secondly, the researcher can identify and access the "experts" to discuss this problem; and finally, the researcher can forecast the type of results that may be obtained from these experts through the Delphi method (after Linstone and Turoff, 1975; Ziglio, 1996).

The Delphi method has been used widely in business (Kaynak et al., 1994; Addison, 2003), nursing and healthcare (Jenkins and Smith, 2004; Keeney et al., 2006; McKenna, 1994), and communications education (Smith, 1997). In public relations research, as noted earlier, there have been several major national and international studies using this method (McElreath, 1980, 1989; McElreath and Blamphin, 1994; White and Blamphin, 1994; Synnott and McKie, 1997; van Ruler et al., 2004; Boynton, 2006). There are no set rules for Delphi studies (Keeney et al., 2006; Evans, 1997), although they are characterized by a structured process of questionnaires or rounds of discussion until a group consensus is reached (Beretta, 1996; Green et al., 1999). These questions are discussed by a panel of "experts" or oracles, hence the Delphi name. The popularity of this method arises because it can be conducted semi-anonymously amongst respondents who are geographically dispersed. For example, Synnott and McKie's 1997 study covered 13 nations in Asia-Pacific and van Ruler et al. (2004) included between 22 and 25 European countries.

A Delphi study typically has two or three rounds of contact with the experts in which comments are first elicited, then summarized and returned for further discussion. Ideally, they would circulate until the group reaches consensus, which can range from 51 percent 


\section{Ml Macrothink}

International Journal of Accounting and Financial Reporting ISSN 2162-3082 2012, Vol. 2, No. 2

(Loughlin and Moore, 1979) to 75 percent (Keeney in McKenna et al., 2000), although the literature does not specify a "consensus threshold". McKenna (1994) found that most statements achieved a consensus of over 70 percent. The reality is that most Delphi studies are completed by a third and final round because of time constraints, participant fatigue, funding for the research and the design of the study (Keeney et al., 2006). Until recently, most Delphi studies have been conducted by post or some other paper-based method (Kendall, 1996) and, latterly, by email. The use of email or internet-based methods has speeded up the process. Boynton (2006) reports use of the internet-based Survey Monkey software for a Delphi study on ethical decision making in public relations had shortened the distribution and response times. However, her 36 percent response rate from an expert panel was no better (and possibly worse) than the previously conventional mail or paper-based methodology. For example, Synnott and McKie (1997) had a response of 48 percent to their initial approach to panels, as did White and Blamphin (1994). van Ruler et al. (2004) using email as their communication tool, however, had a higher initial response rate of 84 percent although this had dropped to 62 percent in the final round. It appears that the selection of the panel and the initial approach may play an important role in gaining and maintaining high levels of continuing participation. Response rates to questionnaires are frequently very low and researchers often have to send out reminder letters or emails to panelists (Keeney et al., 2006). To enhance responses, researchers need to consider whether those who are being selected as "experts" will be prepared to engage in a study that may take much more time and effort than quantitative surveys do.

\subsubsection{The formal organization of a Delphi process}

In the following, a more 'standard' procedure is described.

\section{Organisation of the Delphi-Process}

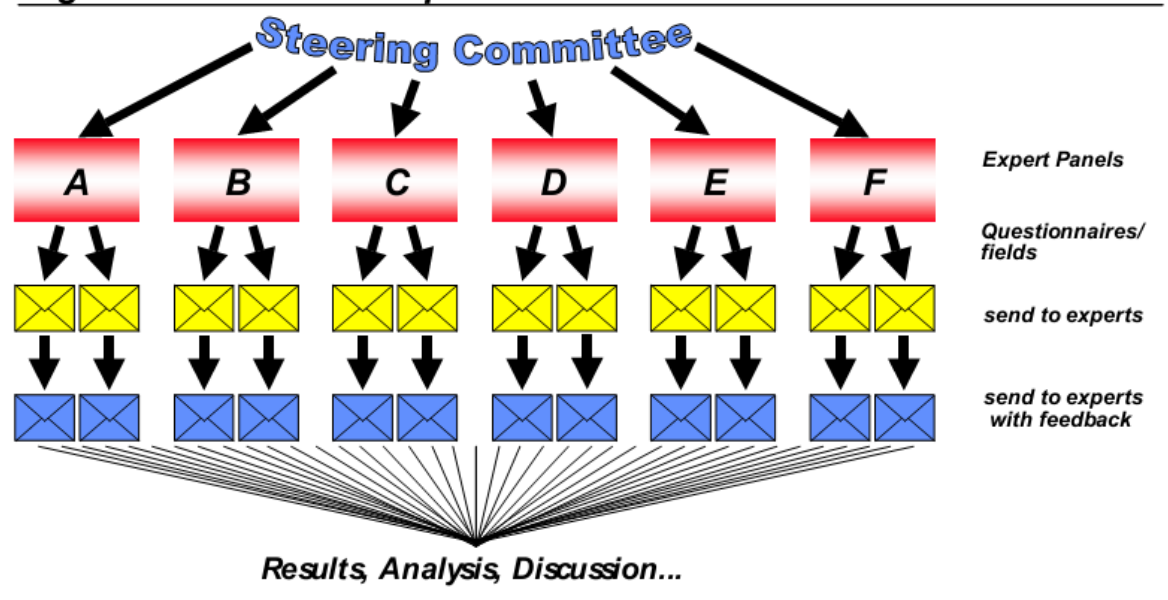

The first step is to found a steering committee (if you need one) and a management team with sufficient capacities for the process. Then expert panels to prepare and formulate the statements are helpful unless it is decided to let that be done by the management team. The whole procedure has to be fixed in advance: Do you need panel meetings or do the teams work virtually. Is the questionnaire an electronic or a paper one? This means, that logistics 


\section{Al Macrothink}

International Journal of Accounting and Financial Reporting

ISSN 2162-3082

2012, Vol. 2, No. 2

(from Internet programming to typing the results from the paper versions) have to be organized. Will there be follow-up work-shops, interviews, presentations? If yes, these also have to be organized and pre-pared. Printing of brochures, leaflets, questionnaire, reports have also be considered. The last organizational point is the interface with the financing organization if this is different from the management team (kerst, 2001).

\section{Hypotheses development}

There are a growing number of empirical studies on firms' non-financial disclosure. Increasingly rigorous content analysis of published corporate reports has been employed, with perspectives from stakeholder and, political economy theories, information economics and risk management (Belal and Owen, 2007). The common normative theme within the academic literature is that CSR reporting enhances accountability (Bebbington et al., 2008). Indeed, many authors have proposed that legitimacy theory provides an explanatory frame for social and environmental disclosure (Deegan, 2002).

With respect to the quantity of non-financial reports, there is growing support that the following factors are associated with greater disclosure of environmental information through corporate communications: firm size, membership in an industry facing significant environmental issues, financial performance, media exposure, and being subject to regulatory proceedings (Adams, 2002).

There have been a number of studies looking specifically at social and environmental, information across countries (Adams et al., 1998). They provide some evidence of differences in the amount and types of disclosures across countries. The extent of these differences is difficult to determine because of the different characteristics (for example size and industry composition) of companies making up the samples from each country. In addition, the extent to which these apparent differences in reports are determined by, for example: culture; the extent of regulations demanding social (and environmental) responsibility; and, the power of pressure groups, is under-theorized.

The other item measures to what extent the annual reports discloses information in terms of business opportunities and risks. Jonas and Blanchet (2000) refer to the complementation of financial information by non-financial information, when referring to predictive value, and the knowledge that can be obtained of business opportunities and risks.

Consequently, I will hypothesize different factors that influence investment decisions:

H1: Provide non-financial information related to the situation of the company, is one factor that can influence investment decisions.

$\mathrm{H} 2$ : Provide nonfinancial information relating to potential future obligations of the Company, is one factor that can influence investment decisions.

H3: Provide non-financial information relating to the company's operating system, is one factor that can influence investment decisions.

H4: Provide non-financial information about the company's strategy, is one factor that can 
influence investment decisions.

H5: providing nonfinancial information to improve the company's performance in relation to welfare, health and education, are the factors that affect investment decisions.

H6: Provide non-financial information related to the development of human activities, is one factor that can influence investment decisions.

H7: Provide non-financial information relating to the composition of the workforce, is one factor that can influence investment decisions.

H8: Provide nonfinancial information relating to corporate social performance, is one factor that can influence investment decisions.

H9: Provide nonfinancial information relating to risk analysis firm, is one factor that can influence investment decisions.

\section{Research method}

\subsection{This Delphi study}

In the case of this research the Delphi study was developed and conducted over two rounds. The respondents from academics that had Fields of accounting and economics and investment managers invited to participate. More links with panelists was via electronic mail which proved to be convenient and quite immediate. Geographical base for this study was public of Iran. Round one of the study commenced in Tir 1391, with a questionnaire being electronically posted to panelists. The questionnaire contained a total of 58 variables with likert scale. In reality this first Delphi round took nine week. 72 Panelists responded via electronic mail and visiting. Descriptive statistics illustrated in figure 1 and table 1 . In round two gave statistical feedback to panelist about the group response and asked for changes or answer. The study was deemed complete after two rounds. A number of factors led to this decision.

As I said i collected data through the use of a questionnaire in two rounds. The questionnaires sent for academics that had Fields of accounting and economics and investment managers from public of Iran as professional investors.

In First round the questionnaire was semi-open and consists out of 58 variables which show factors that can influence investment decisions. The respondents were asked to evaluate each variable. They indicated their Importance concerning those variables on a scale of 1 to 5 . The meaning of the scale is as follow; $1=$ very little, $2=$ low, $3=$ average, 4 high, $5=$ a lot.

In second round, the questionnaire was closed and consists out of 60 variables which show factors that can influence investment decisions. The respondents were asked to evaluate each variable according to average, median and ranking for each item that we concluded in first round. They indicated their Importance concerning those variables again on a scale of 1 to 5 . The meaning of the scale is as follow; $1=$ very little, $2=$ low, $3=$ average, 4 high, $5=$ a lot. 


\section{Macrothink}

\section{Research results}

\subsection{The first round:}

We examined the disclosure of nonfinancial information across a sample of 130sizes. Our research assessed the extent of current disclosure practices across 58 specific types of nonfinancial information. The total of questionnaires that received was 72. In this round we found that respondents have not reached a consensus. Because answer more than half of them were out of quartile range.

\subsection{The second round:}

We conducted another survey across a sample of 72 sizes (Respondents of first round).Our research assessed the extent of current disclosure practices across 60 specific types of nonfinancial information. The total of questionnaires that received was 65 . In this round we found that respondents have reached a consensus Due to the following reasons:

1. More than $50 \%$ experts chose 25 nonfinancial measures as the first nonfinancial measures (Loughlin and Moore, 1979).

2. Standard deviation in first round was $75 \%$ and this mount decrease in second round $(64 \%)$.

3. Kendall coefficient of concordance (w) for answers was in round two was 0.59 that show strong agreement.

4. Grow of Kendall coefficient of concordance $(w)$ in second round is a little (0.025).

\section{Test Statistics}

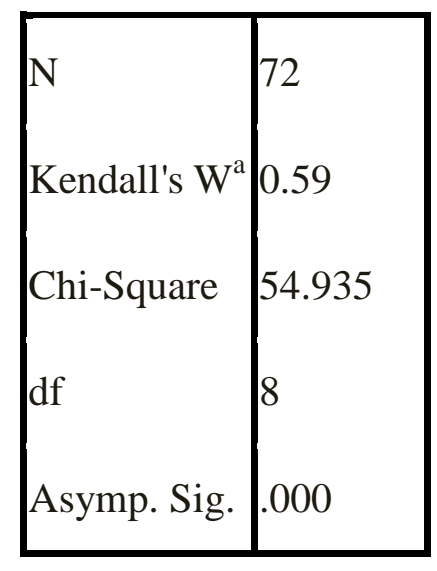

a. Kendall's Coefficient

of Concordance

Descriptive statistics showed in frequency tables and charts: 


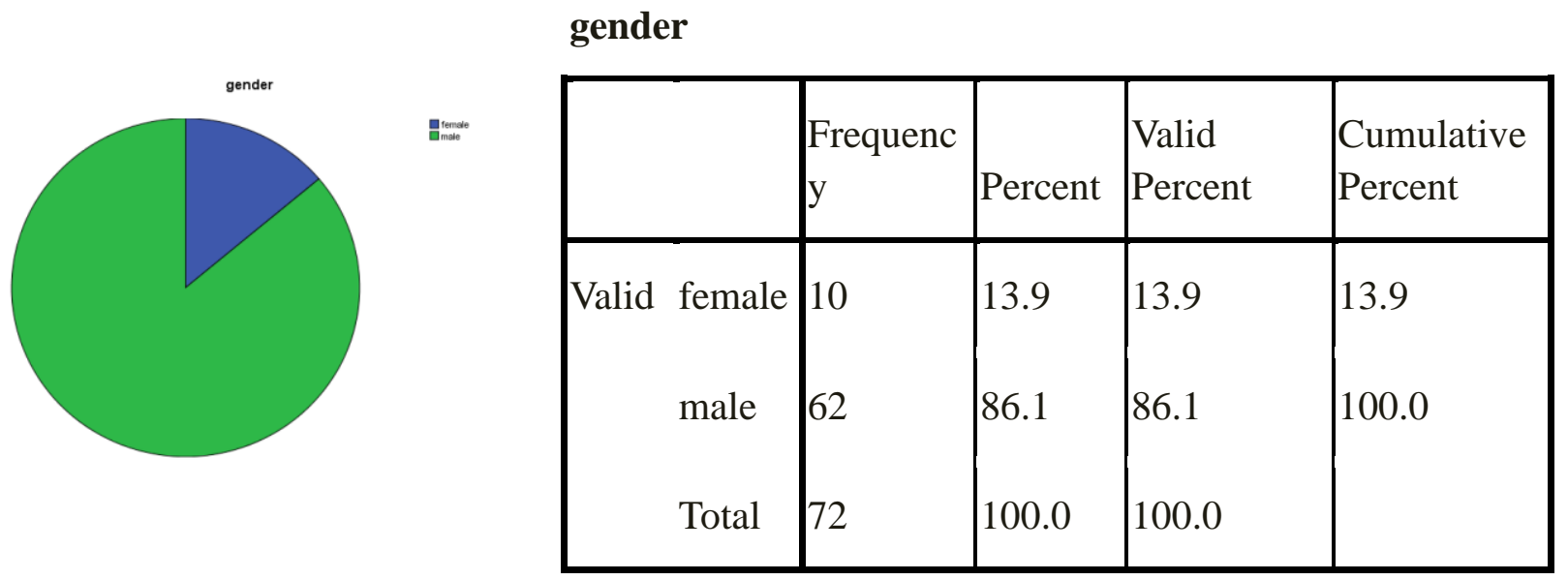

Figure 1: gender (The first round)

Table1: gender (The first round)

gender

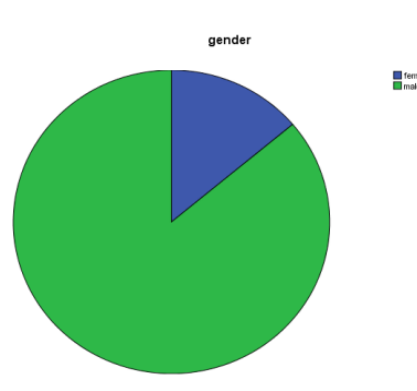

\begin{tabular}{|l|l|l|l|l|}
\hline & $\begin{array}{l}\text { Frequenc } \\
\text { y }\end{array}$ & Percent & $\begin{array}{l}\text { Valid } \\
\text { Percent }\end{array}$ & $\begin{array}{l}\text { Cumulative } \\
\text { Percent }\end{array}$ \\
\hline Valid female & 11 & 17.0 & 17.0 & 17.0 \\
male & 54 & 83.0 & 83.0 & 100.0 \\
Total & 65 & 100.0 & 100.0 & \\
\hline
\end{tabular}

Figure 2: gender (The second round)

Table2: gender (The second round) 


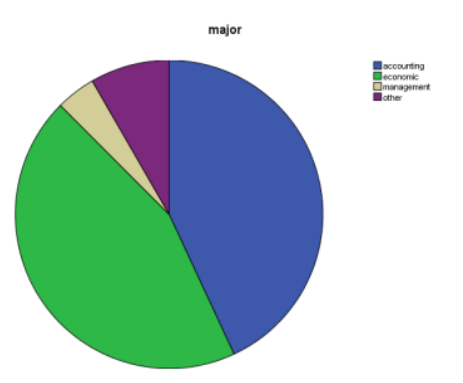

Figure 3: major (The first round) Table3: major (The first round)

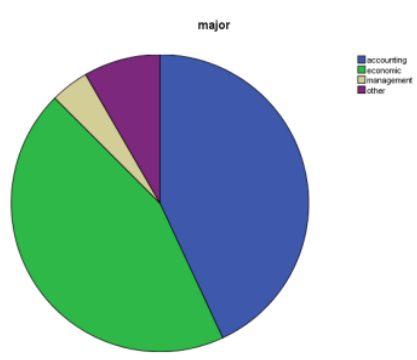

Figure 4: major ((The second round) major

\begin{tabular}{|l|l|l|l|l|}
\hline & $\begin{array}{l}\text { Frequenc } \\
\text { y }\end{array}$ & Percent & $\begin{array}{l}\text { Valid } \\
\text { Percent }\end{array}$ & $\begin{array}{l}\text { Cumulative } \\
\text { Percent }\end{array}$ \\
\hline Valid accounting & 31 & 43.1 & 43.1 & 43.1 \\
economic & 32 & 44.4 & 44.4 & 87.5 \\
$\begin{array}{l}\text { managemen } \\
\text { t }\end{array}$ & 3 & 4.2 & 4.2 & 91.7 \\
other & 6 & 8.3 & 8.3 & 100.0 \\
Total & 72 & 100.0 & 100.0 & \\
\hline
\end{tabular}

major

\begin{tabular}{|l|l|l|l|l|}
\hline & $\begin{array}{l}\text { Frequenc } \\
\text { y }\end{array}$ & Percent & $\begin{array}{l}\text { Valid } \\
\text { Percent }\end{array}$ & $\begin{array}{l}\text { Cumulative } \\
\text { Percent }\end{array}$ \\
\hline Valid accounting & 29 & 45.0 & 45.0 & 45.0 \\
economic & 31 & 48.0 & 48.0 & 96.0 \\
$\begin{array}{l}\text { managemen } \\
\text { t }\end{array}$ & 2 & 3.0 & 3.0 & 96.0 \\
other & 3 & 4.0 & 4.0 & 100.0 \\
Total & 65 & 100.0 & 100.0 & \\
\hline
\end{tabular}

Table 4: major (The second round) 


\section{Macrothink \\ International Journal of Accounting and Financial Reporting

First to test the hypothesis the following procedure is do:

Kolmogorov test is done:

\begin{tabular}{|c|c|c|}
\hline & & mean \\
\hline \multicolumn{2}{|c|}{$\mathrm{N}$} & 72 \\
\hline Normal Parameters ${ }^{\mathrm{a}}$ & Mean & 3.3699 \\
\hline \multirow{4}{*}{ Most Extreme Differences } & Std. Deviation & .34998 \\
\hline & Absolute & .097 \\
\hline & Positive & .097 \\
\hline & Negative & -.071 \\
\hline \multicolumn{2}{|c|}{ Kolmogorov-Smirnov Z } & 2.45 \\
\hline \multicolumn{2}{|c|}{ Asymp. Sig. (2-tailed) } & .001 \\
\hline
\end{tabular}

Table 5:One-Sample Kolmogorov-Smirnov Test

Data is non-normally distributed. We used a non-parametric equivalent of the 1 sample t-test (1 Sample Sign Test).The SIGN TESTsimply computes a significance test of a hypothesized median value for a single data set. Like the 1 SAMPLE T-TEST you can choose whether you want to use a one-tailed or two-tailed distribution based on your hypothesis; basically, do you want to testwhether the median value of the data set is equal to some hypothesized value (H0: $\eta=\eta_{\mathrm{o}}$ ), or doyou want to test whether it is greater (or lesser) than that value (H0: $\eta>$ or $<\eta \mathrm{o})$. Likewise, you can choose to set confidence intervals around $\eta$ at some $\alpha$ level and see whether $\eta$ falls withinthe range. This is equivalent to the significance test, just as in any T-TEST.

Sign test of median $=3.000$ versus $<3.000$

$\mathrm{N}$ Below Equal Above P Median

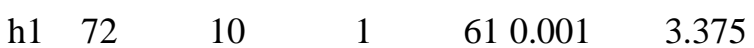




\section{Al Macrothink \\ International Journal of Accounting and Financial Reporting \\ ISSN 2162-3082 2012, Vol. 2, No. 2}

\section{Table 6: Sign Test for Median: h1}

As you see in above table, p-value is under 0.05 and we can conclude h1 is accepted. For other hypothesis we have the same table that show sign-test consist of p-value.

Sign test of median $=3.000$ versus $<3.000$

\begin{tabular}{cccccccc} 
N & Below & Equal & Above & \multicolumn{3}{c}{ P Median } \\
h2 & 72 & 19 & 6 & 47 & & 0.085 & 3.500
\end{tabular}

Table 7: Sign Test for Median: h2

Sign test of median $=3.000$ versus $<3.000$

N Below Equal above P Median

$\begin{array}{llllll}\text { h3 } & 72 & 17 & 13 & 42 & 0.001\end{array}$

Table8: Sign Test for Median: h3

Sign test of median $=3.000$ versus $<3.000$

$\mathrm{N}$ Below Equal above P Median

Table9: Sign Test for Median: h4

Sign test of median $=3.000$ versus $<3.000$

N Below Equal above P Median

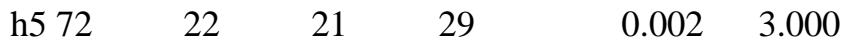


Table 10: Sign Test for Median: h5

Sign test of median $=3.000$ versus $<3.000$

$\mathrm{N}$ Below Equal above P Median

$\begin{array}{llllll}\text { h6 } 72 & 17 & 10 & 45 & 0.509 & 3.500\end{array}$

Table 11: Sign Test for Median: h6

Sign test of median $=3.000$ versus $<3.000$

N Below Equal above P Median

$\begin{array}{llllll}\text { h7 } 72 & 10 & 23 & 39 & 0.987 & 4.000\end{array}$

Table 12: Sign Test for Median: h7

Sign test of median $=3.000$ versus $<3.000$

$\mathrm{N}$ Below Equal above P Median

$\begin{array}{llllll}\text { h8 } 72 & 19 & 14 & 39 & 0.001 & 3.500\end{array}$

Table13: Sign Test for Median: h8

Sign test of median $=3.000$ versus $<3.000$

$\mathrm{N}$ Below Equal above P Median

$\begin{array}{lllll}\text { h9 } 72 & 9 & 16 & 47 & 0.048\end{array}$

\section{Table14: Sign Test for Median: h9}

As the statistical tables show hypothesis number one, three, four, five, eight and nine are accepted so we concluded that non-financial information related to the situation of the company, relating to the company's operating system, about the company's strategy, nonfinancial information to improve the company's performance in relation to welfare, health and education, relating to corporate social performance and nonfinancial information relating 
to risk analysis firm, are effective on making decision.

\section{Conclusion}

It is well accepted that Non-financial performance measurement plays many important roles in running an organization. These include types of risks, General situation of the company, and other variables. For a long time, managers had primarily used accounting-based measures for these purposes. But with the advent of new competitivealities argued that accounting-based performance measurement systems are no longer adequate.

This study investigates how this Non-financial information is important for academics and managers as proxy for investors with taking advantage of Delphi. In the other word the main objective of this study is to undertake a detailed, descriptive analysis into whether nonfinancial performance indicators affect investment decision processes and the information they utilize in performing company valuations. The examination of how professional financial report users utilize non-financial disclosures is relevant to managers in companies considering enhanced disclosure policies, regulators considering mandating disclosure of this type of information, as well as to professional and non-professional financial report users in evaluating companies.

A questionnaire is used to measure how this information is important. Sample including academics that had fields of accounting and economics and investment managers from public of Iran. The results of the questionnaires indicate that:

Some items like: situation of the company, non-financial information relating to the company's operating system, about the company's strategy, information to improve the company's performance in relation to welfare, health and education, corporate social performance and information relating to risk analysis firm can have important effect on decision making but investors have less attention to others.

This project is meant to better identify those types of information most desired by investors currently, and to identify whether and where there are areas where improvements in data comparability, clarity and reliability would facilitate investors' use of information they find material to their decision-making.

The results of this study offer academics, investors, corporations and regulators a clearer picture both of investor desires for nonfinancial information and the ways in which various forms of reporting are used. The results can inform choices about which regulatory approach might be best applied to nonfinancial reporting. They can also support corporate and investor efforts to supplement that regime with voluntary corporate reporting on specific nonfinancial information types.

\section{Limitations}

The study also has a number of limitations. In reality Delphi is not without limitations. The consensus reached in a Delphi may not be a true consensus; it may be a product of specious or manipulated consensus. A specious consensus does not contain the best judgment. Instead, it is a compromise position (Mitroff\&Turoff, 1975).

Delphi appears to be a straightforward approach to doing research in the area of forecasting 
and for building consensus. Researchers, at first glance, think of Delphi as a simple technique that can be done easily. However, one must carefully consider the problems associated with Delphi before designing a Delphi study. Linstone and Turoff $(1976$, p.6) suggested that there are five common reasons for Delphi to fail: 1. Imposing monitor views and preconceptions of a problem upon the respondent group by over specifying the structure of the Delphi and not allowing for contribution of other perspectives related to the problem. 2. Assuming that Delphi can be a surrogate for all other human communications in a given situation.

Delkey (1963) pointed out that Delphi is not sufficient to be a defining property for an uncertain

question because the expert's cultural bias can lead to similar answers to some questions which in fact are poorly known; or there could be an instance where the experts legitimately do not know the answer. According to Linstone and Turoff (1975), the virtual problems do not affect the utility of Delphi but rather how to select the respondent group.

Barnes (1987) has listed additional disadvantages of technique: 1. Judgments are those of a select group of people and may not be representative; 2. Tendency to eliminate extreme positions and force a middle-of-the-road consensus; 3. More time consuming than the nominal group process; 4 . Should not be viewed as a total solution;5. Requires skill in written communication; 6. Requires adequate time and participant commitment (about 30 to 45 days to complete the entire process) (p.63).

\section{Recommendations}

The reporting of non-financial information is more than just an externally directed process with the auditor as assurance provider. It must be part of the governance structure and focus on users' wishes. Non-financial information must receive an explicit place within governance, as part of which extensive communication on relevance and reliability is required with all parties involved. Rules are required to be able to safeguard this. Providing direction is impossible without information. What is relevant information will primarily have to be determined by the governors in consultation with stakeholders. All parties involved, from governors to users, have to realise that basic principles will apply to reliable non-financial information as well. There has to be a focus on clarity, consistency and transparency.

The goal of our research was to better assess both the supply and demand of nonfinancial reporting in the current investment climate. We believe that the results of this study offer academics, investors, corporations and regulators a clearer picture both of investor desires for nonfinancial information and the ways in which various forms of reporting are used. The results can inform choices about which regulatory approach might be best applied to nonfinancial reporting. They can also support corporate and investor efforts to supplement that regime with voluntary corporate reporting on specific nonfinancial information types.

\section{Reference list}

1. AccountAbility AA1000 Account Ability Principles Standard (AA1000APS 2008), 2008, 2 Jul. 2009. http://www.accountability21.net/aa1000aps

2. Adams, C. A. Internal organizational factors influencing corporate social and ethical 
reporting: Beyond current theorizing. Accounting, Auditing \& Accountability Journal (2002), 15 (2): 223-50.

3. Adams, C. A., Hill, W.-Y, Roberts,C. B. Corporate social reporting practices in Western Europe: legitimating corporate behavior? British Accounting Review (1998), 30: 1-21.

4. Addison, T. (2003), "E-commerce project development links: evidence from a Delphi survey", International Journal of Information Management, Vol. 23 No. 1, pp. 25-40.

5. American Accounting Association Financial Accounting Standards Committee. (2002). Recommendations on disclosure of non-financial performance measures. Accounting Horizons, 16(4), 353-362.

6. Barnes, J. L. (1987). An international study of curricular organizers for the study of technology. Unpublished doctoral dissertation, Virginia Polytechnic Institute and State University, Blacksburg, Virginia.

7. Bebbington, J., Larringa, C., Moneva, J. M. Corporate social reporting and reputation risk management. Accounting, Auditing \& Accountability Journal (2008), 21 (3): 337-61.

8. Belal, A. R., Owen, D. L. The views of corporate managers on the current state of, and future prospects for, social reporting in Bangladesh. Accounting, Auditing \& Accountability Journal (2007), 20 (3): 472-494.

9. Bell, T. B., M. Peecher, and I. Solomon. 2002. The 21st Century Public-Company Audit: Conceptual Elements of KPMG's Global Audit Methodology. Montvale, NJ: KPMG.

10. Beretta, R. (1996), “A critical review of the Delphi technique”, Nurse Researcher, Vol. 3 No. 4, pp. 79-89.

11. Boynton, L. (2006), "What we value: a Delphi study to identify key values that guide ethicaldecision-making in public relations", Public Relations Review, Vol. 32 No. 4, pp. 325-30.

12. Brown, S., Lo, K. and Lys, T. (1998), "Use of R2 in accounting research: measuring changes in value relevance over the last four decades", Journal of Accounting and Economics, Vol. 28, pp. 83-115.

13. Chandra, U., A. Procassini, and G. Waymire. 1999. The use of trade association disclosures by investors and analysts: Evidence from the semiconductor industry. Contemporary Accounting Research16: 643-670.

14. Chang, J. (1998), "The decline in value relevance of earnings and book values", working paper,Harvard University, Cambridge , MA.

15. Dalkey, N., \&Helmer O. (1963). An experimental application of the Delphi method to the use of experts. Management Science, 9(3), 458-467.

16. Dawson, M.D. and Brucker, P.S. (2001), "The utility of the Delphi method in MFT 


\section{1ll Macrothink}

International Journal of Accounting and Financial Reporting

ISSN 2162-3082

2012, Vol. 2, No. 2

research", TheAmerican Journal of Family Therapy, No. 29, pp. 125-40.

17. Deegan, C. The legitimising effect of social and environmental disclosures - a theoretical foundation. Accounting, Auditing \& Accountability Journal (2002), 15 (3): 282-311.

18. Dempsey, S., J. D. Gatti, D. J. Grinnel, and W. Cats-Baril. 1997. The use of strategic performance variables as leading indicators in financial analysts' forecasts. Journal of Financial Statement Analysis 2 (4):61-79.

19. Eccles, R., R. Herz, E. Keegan, and D. M. H. Phillips. 2001. The ValueReporting Revolution. New York, NY: Wiley.

20. Enhanced Business Reporting Consortium (EBRC). (2005). The enhanced business reporting framework. Enhanced Business Reporting Consortium. Available from: http://www.ebr360.org/downloads/ebr.framework.publicexposure.2005.10.pdf.

21. FASB (1999). International standard setting: a vision for the future. Norwalk.

22. Financial Accounting Standards Board_FASB_. 2001. Improving Business Reporting: Insights into Enhancing Voluntary Disclosures. Steering Committee Report, Business Reporting Research Project. Norwalk, CT: FASB.

23. Francis, J. and Schipper, K. (1999), "Have financial statements lost their relevance?",Journal of Accounting Research, Vol. 37, pp.319-52.

24. Global Reporting Initiative Sustainability Reporting Guidelines, 2007, 2 Jul. 2009 http://www.globalreporting.org/Home

25. Green, B., Jones, M., Hughes, D. and Williams, A. (1999), "Applying the Delphi technique in astudy of GPs information requirements", Health \& Social Care in the Community, Vol. 7No. 3, pp. 198-205.

26. IASB (2008). Exposure Draft on an improved Conceptual Framework for Financial Reporting: The Objective of Financial Reporting and Qualitative Characteristics of Decision-useful Financial Reporting Information. London.

27. Institute of Chartered Accountants in England \&Wales (ICAEW). (2003).Information for better markets - new reporting models for business. London: Institute of Chartered Accountants in England \& Wales.

28. Jenkins, D.A. and Smith, T.E. (2004), "Applying Delphi methodology in family therapy research",Contemporary Family Therapy, No. 16, pp. 411-30.

29. Jonas, G. \& Blanchet, J. (2000). Assessing Quality of Financial Reporting. Accounting Horizons, 14(3), 353-363.

30. Kaplan, R. S., \& Norton, D. P. (1992). The balanced scorecard - measures that drive performance. Harvard Business Review, 70(5), 71-79.

31. Kaplan, R. S., and D. Norton. 2001a.The Strategy-Focused Organization. Boston, MA: Harvard Business School Press. 


\section{Macrothink}

International Journal of Accounting and Financial Reporting

ISSN 2162-3082

32. Kaplan, R. S., and D. Norton. 2001b. Transforming the balanced scorecard from performance measurement to strategic management. Part I. Accounting Horizons 15 _1_: 87-104.Kaplan, R. S., and D. Norton.Transforming the balanced scorecard from performance measurement to strategic management. Part II. Accounting Horizons 15 _2_: 147-161.

33. Kaynak, E., Bloom, J. and Liebold, M. (1994), "Using the Delphi technique to predict futuretourism potential”, Marketing Intelligence \& Planning, Vol. 12 No. 7, pp. 18-29.

34. Keeney, S., Hasson, F. and McKenna, H. (2006), "Consulting the oracle: ten lessons from using theDelphi technique in nursing research", Journal of Advanced Nursing, Vol. 53 No. 2, pp. 205-12.

35. Kendall, R. (1996), Public Relations Campaign Strategies: Planning for Implementation, 2nd ed.,Longman, New York, NY.

36. Kerstin Cuhls, "Delphi method" (2001), Fraunhofer Institute for Systems and Innovation Research,Germany.

37. Lev, B. and Zarowin, P. (1999), "The boundaries of financial rep o $r$ ting and how to extend them", Journal of Accounting Research, Vol. 37, Supplement, pp. 353-85

38. Linstone, H. A., \&Turoff, M. (1975). The Delphi method: Techniques and applications. Reading, Massachusetts: Addison-Wesley Publishing Company.

39. Linstone, H.A. and Turoff, M. (1975), "Introduction", in Linstone, H.A. and Turoff, M. (Eds), TheDelphi Method: Techniques and Application, Addison-Wesley, London, pp.3-16.

40. Loughlin, K.G. and Moore, L.F. (1979), "Using Delphi to achieve congruent objectives andactivities in a paediatrics department", Journal of Medical Education, Vol. 54 No. 2, pp. 101-6.

41. McElreath, M.P. (1980),Priority Research Questions for Public Relations in the 1980s, Foundationfor Public Relations Research and Education, New York, NY.

42. McElreath, M.P. and Blamphin, J.M. (1994), "Partial answers to priority research questions - andgaps - found in the Public Relations Society of America's body of knowledge", Journal ofPublic Relations Research, Vol. 6 No. 2, pp. 69-103.

43. McKenna, H. (1994), "The Delphi technique: a worthwhile approach for nursing?”,JournalofAdvanced Nursing, No. 19, pp. 1221-5.

44. Mitroff, I. I., \&Turoff, M. (1975). Philosophical and methodological foundations of Delphi. In H. A. Linstone\& M. Turoff (Eds.), The Delphi method: Techniques and applications (pp. 17-35). Reading MA: Addison-Wesley Publishing Co.

45. Peecher, M., R. Schwartz, and I. Solomon. 2007. It's all about audit quality: Perspectives on strategic systems auditing. Accounting, Organizations and Society 32: 463-485.

46. Peecher, M., R. Schwartz, and I. Solomon. 2007. It's all about audit quality: 
Perspectives on strategic systems auditing. Accounting, Organizations and Society 32: 463-485.

47. Rajgopal, S., M. Venkatachalam, and S. Kotha. 2002. Managerial actions, stock returns, and earnings: The case of business-to-business Internet firms. Journal of Accounting Research 40 (2): 529-556.

48. Smith, M.A. (1997), "Perceptions of quality in journalism and communications education: aDelphistudy", Journal of the Association for Communication Administration, Vol. 1,pp. 32-50.

49. Snotty, G. and McKee, D. (1997), "International issues in PR: researching research andprioritizingpriorities",Journal of Public Relations Research, Vol. 9 No. 4, pp. 259-82.

50. Van Ruler, B., Verdict, D., Bu” tschi, G. and Flodin, B. (2004), "A first look for parameters of public relations in Europe", Journal of Public Relations Research, Vol. 16 No. 1, pp. 35-63.

51. White, J. and Blamphin, J. (1994), Priorities for Research into Public Relations Practice in the United Kingdom, City University Business School/Rapier Research, and London.

52. Ziglio, E. (1996), "The Delphi method and its contribution to decision making", in Adler, M. andZiglio, E. (Eds), Gazing into the Oracle: the Delphi Method and its Application to Social Policy and Public Health, Jessica Kingsley Publishers, London, pp. 3-26. 